\title{
Teacher resources available to facilitate inclusive educational practices in pre-schools within Obio- Akpor in Nigeria
}

\author{
Chima-Uzosike Ngozi, Michael Subbey \\ Department of Early Childhood Education, Faculty of Educational Studies, University of Education, Winneba, Ghana
}

\begin{abstract}
Education is one of the tools humanity uses to help in developing society through man. Since society needs the contributions of everyone in developing it, a lot of efforts are made through research and others to educate almost everybody in society in contributing to it. The mind of the individual has to be trained to a level that it would be beneficial to each member of the society.

In creating a better society, we could not depend on one person in carrying out the desired development else society or community would lag behind. Hence every person whether with any form of disability or not has to be developed to his/her full potential. Inclusive education has been internationally recognized as a philosophy for attaining equity, justice and quality education for all children, especially those who have been traditionally excluded from mainstream education for reasons of disability, ethnicity, gender or other characteristics (Nguyet \& Ha, 2010).
\end{abstract}

\section{INTRODUCTION}

I nclusive education has been widely defined as a process intended to respond to students' diversity by increasing their participation and reducing exclusion within and from education (Nguyet \& Ha, 2010). This definition considers inclusive education beyond disability issues and includes quality teaching, the attendance, involvement and achievement of all students, especially those who, for different reasons, are excluded or at risk of being marginalized (UNESCO, 2009).

The Salamanca Statement on Principles, Policy and Practice in Special Needs Education (Salamanca Declaration) from 1994 is the cornerstone of understanding the practice of inclusive education. Inclusive education happens when children with and without disabilities participate and learn together in the same classes with the right support in place. Research showed that when a child with disability attends classes alongside with his/her peers who were not having any disability, it benefits the child with disability (UNESCO, 2009).

Children with disabilities and their families continue to face significant barriers to accessing inclusive high-quality early childhood programs and too many preschool children with disabilities are only offered the option of receiving special education services in settings separate from their peers without disabilities (Anaby, Law, Coster, Bedell, Khetani \&
Teplicky, 2014). It is well documented that the beginning years of all children's lives are critical for building the early foundations of learning and wellness needed for success in school and later in life. During these years, children's brains develop rapidly, influenced by the experiences they share with their families, teachers, peers, and in their communities. Like all children, it is critical for children with disabilities to be exposed to a variety of rich experiences where they can learn in the context of play and everyday interactions and engage with their peers with and without disabilities.

The fundamental principle of the inclusive school is that all children should learn together, wherever possible, regardless of any difficulties or differences they may have. Inclusive schools must recognize and respond to the diverse needs of their students, accommodating both different styles and rates of learning and ensuring quality education to all through appropriate curricula, organizational arrangements, teaching strategies, resource use and partnerships with their communities. There should be a continuum of support and services to match the continuum of special needs encountered in every school (Salamanca Framework for Action, 1994).

Gardner and Kelly (2008) postulate that educators must "foster learning environments that are integrally attentive to issues of meaning-making, critical reflection, social justice, diversity, care, collaboration, and community" (p. 1). Therefore teachers who promote inclusive education are caring. They consider a school as a community, value good personal and interpersonal relationships and create optimum learning opportunities for all students (Lindsay, 2003; Sweetland, 2008).

One of the requirements for effective implementation of inclusive education is that teachers must be adequately prepared (Moore \& Gilbreath, 1998). This can be accomplished by providing experiences which could provide prospective teachers the ability to develop creative ways and skills in solving problems. Teachers are to view situations from different perspectives since they are key to educational change and school improvement and that teachers do not merely deliver the curriculum, they develop, define and interpret it too (Ainscow, 1997). It is what teachers think, believe and do in the classroom that ultimately shape the kind of learning that their students get. 
In Nigeria and in other developing countries, individuals with disabilities constitute a significant portion of the population due to inadequacies in nutrition, health care, social services, conflicts, and the impacts of natural disasters. It has been suggested that 80 percent of people with disabilities in the world live in Nigeria and other developing countries (Bernheimer, Gallimore, \& Weisner, 1990). Reliable data on the population of persons with disabilities in Nigeria is lacking. No valid census on persons with disabilities has been conducted in the country since independence from Britain in 1960. However, according to World Health Organisation and the World Bank estimates that disabilities occur in at least 15 percent of the world's population (i.e. one billion people), it can be assumed that there are several millions of people with disabilities in Nigeria. Like other segments of the population, people with disabilities in Nigeria have the capacity to contribute meaningfully to national development if they are supported through education and related services necessary. The marginalization that persons with disabilities in Nigeria encounter include challenges in accessing education and related services. Although most educational institutions for learners with disabilities in Nigeria are segregated, the need for these learners to be educated in regular schools was acknowledged in the NPE document (Eleweke, 2016). The question is: Are the necessary teacher resources and supports, to ensure the success of inclusive programmes, available in the country? Clearly, the provision of effective education and related services to individuals with disabilities in the country requires more inclusive environments to assist with fighting discrimination and enhancing equality and access to programmes and services (Eleweke, 2016).

In Nigeria, the Joint National Association of Persons with Disability (JONAPWD) has revealed that children with disabilities remain out of school because virtually all primary and secondary schools in Nigeria are designed, built and managed in ways that are totally not inclusive of and not accessible to them (Garuba, 2003). The National President of JONAPWD has indicated that unfortunate about seven million children with disabilities are out of school in spite of the provision of the Universal Basic Education (UBE) Act of 2004 in the country. Consequently, the group in $14^{\text {th }}$ march, 2016 called on President Mohammed Buhari led government to review all legal policy frameworks on education at the national and state levels to accommodate more children who are physically impaired in the country. Ekaete was speaking at the media launch of the Baseline Survey conducted in AkwaIbom, Kwara states and the Federal Capital Territory, as part of the ongoing project on Advocacy for Inclusive and Accessible Universal Basic Education for Children with Disabilities in Nigeria supported by USAID Strengthening Advocacy and Civic Engagement (SACE) Programme in Nigeria, in Abuja. JONAPWD President said, it is ironical that basic education remains free and compulsory in the country, but the door still remains shot against children with disabilities in their father land. She indicated that, research has shown that children with disabilities constitute more than 50 percent of the over 10 million out of school children in Nigeria despite the provision of free and compulsory of basic education for all children. According to her, the idea of special school for these categories of children is no longer working because it takes them away from their family and community lives (Obiakor \& Offor, 2012).

The issues of children with disabilities, coping within the formal and the informal structures in the country has been a major challenge to unravel with. It is however very disheartening that, children with disabilities are marginalized in societies of origin, in terms of teaching and learning, disability friendly infrastructure and equity in distribution of resources. In the educational sector, most children with disabilities are cram together with 'abled' children with the same instructions and mode of assessment with no special treatment and care for the children with disabilities. The stigma and the trauma such children go through is more inhuman than the ailment that caused their disability. As a teacher and a social worker in communities with pre-schools, the researcher's observation with casual visit to some of the schools Like State Primary School Ozuoba and Olanada Government State Primary School 1 in Rumuola reveals a very disheartening situation where teachers are not motivated to exhibit maximum care for children with disabilities, such children live in structures that are not disabled friendly and children with disabilities are jammed up with children with no disabilities. These among others constitute a major concern which need to be researched into the available teacher resources to facilitate the inclusion of children with disabilities in Nigeria for effective and holistic development for the less privileged child.

\subsection{Problem statement}

Although teachers in the general education classrooms have positive attitudes towards including children with disabilities in the regular school classrooms, they have limited knowledge of inclusive practices (Hayford, 2007). Most teachers do not provide the individual support to students with disabilities to offer assistance to enable them to overcome their problems and participate in learning successfully (Hayford, 2007). Most general education classroom teachers in Nigeria have limited knowledge in identifying children with special needs. Regular classroom teachers usually express concerns about inclusive education (Hayford, 2007). One of the concerns is that they lack the specialized training required to teach academic, social or adaptive behaviours to children with disabilities (Hayford, 2007).

From the researcher's own personal experience as a teacher and a social worker in communities with schools, her observation through casual visits to some of the schools such as the State Primary School (Ozuba), Olanada State Primary School (Rumuola), just to mention but a few, reveals a worrying situation where teachers are not motivated to exhibit maximum care for children with disabilities. The children with disabilities were jammed up with children with no disabilities. Information gathered from resource teachers 
revealed that teachers in the general classroom have difficulties in adapting the general curriculum to suite the learning needs of special need children. It is against this background that it is necessary to assess teachers' views about material resources available to facilitate inclusive educational practices in pre-schools within Obio-Akpor in Nigeria

\subsection{Purpose of the study}

The purpose of the study was to examine the teacher resources available for the inclusion of children with disabilities in preschools in the Obio-Akpor Local Government Area. Specifically, the study sought to find out about:

1. Views of teachers regarding the resources available for them towards inclusion.

2. Teacher resources available to facilitate inclusive education.

\subsection{Research questions}

The study seeks to answer the following questions:

The study was guided by the following research questions:

1. What are the views of teachers regarding the support services available?

2. What teacher resources are available to facilitate inclusion?

\subsection{Delimitations}

Geographically, the study was restricted to selected preschools, teachers and head teachers in the Obio-Akpor Local Government Area of Nigeria. The study examined the teacher resources available for the inclusion of children with disabilities in pre-schools. The scope of the study was to assess the views of teachers regarding teacher resources available; find out the teacher resources available to facilitate inclusive education; also, the Vygotsky (1978) social development theory and the social model of disability constituted the theoretical bases for the study.

\section{METHODOLOGY}

\subsection{Research Design}

The study employed the descriptive survey design for the study. Descriptive survey design is the one which involves the collection of data in order to test hypothesis or answer research questions concerning the current status of the subject under investigation (Shuttleworth, 2008). This design was chosen because it offers the opportunity to observe, assess and describe the support services available for the inclusion of children with disabilities in pre-schools (nursery two) in the Obio-Akpor Local Government Area. Amedahe (2002) maintains that in descriptive research, accurate description of activities, objects, processes and persons is objective. Therefore, in order to have an objective analysis of the situation so far as teacher resources available for the inclusion of children with disabilities in pre-schools is concerned, the study adopted the descriptive survey design for the study.

\subsection{Research Instruments}

Instrument for data collection is a tool that is used by researcher for collection of data in social science research (Bhandarkar \& Wilkinson, 2010). It is related not only to instrument design, selection, construction, and assessment, but also the conditions under which the designated instruments are administered (Hsu \& Sandford, 2010). The questionnaire was the sole instrument for the study. Two sets of questionnaires (for teachers and headteachers) were designed to collect data for the study. Reasons for the choice of the instrument were that, questionnaire is described as structured instrument for gathering data from a potentially large number of respondents, within a shorter possible time when especially the population is easily accessible (Deng, 2010; Amedahe \& Gyimah, 2005). Again, the researcher used the questionnaire because, the respondents (teachers and head teachers) are literates and it is advantageous whenever the sample size is large enough to make it uneconomical for reasons of time or funds to interview every subject in the study (Osuala, 2005).

Both questionnaires (for teachers and head teachers) were designed into five main sections (section A, B, C, D, \& E). Section A was on the demographic characteristics of the respondents, while sections $\mathrm{B}, \mathrm{C}, \mathrm{D}, \& \mathrm{E}$ looked at the views of teachers regarding teacher resources for inclusion in preschools; teacher resources available to facilitate inclusive education in pre-schools in the Obio-Akpor Local Government Area in Nigeria. The items were the closed ended type to ensure easy and rapid response to the items.

\subsection{Population}

The population for the study comprised all teachers and head teachers in the pre-schools in the Universal Basic Education in the Obio-Akpor Local Government Area. There were 53 public pre-schools in the Obio-Akpor Local Government Area with a population of 53 teachers and 53 head teachers totaling 106 respondents (Obio-Akpor Local Government, 2018). Teachers were involved in the study because, they are in a better position to give information concerning their views on the support services available for the inclusion of children with disabilities. Also, both teachers and head teachers can provide information on the teacher resources available to facilitate inclusive education, as well as how teacher training can influence the inclusion of children with disabilities in preschools.

A population in a research refers to the lager group of people with common observable features to which one hopes to apply the research result (Fraenkel \& Wallen, 2003). Kwabia (2006) posits that social research is an investigation into the actions of people in society. He stressed that these social actors constitute what we call population. Absolutely, when the boundaries of a population are not clearly defined, it may be referred to as "universe". Thus, population can be described as any set of persons or objects that share common characteristics. 


\subsection{Sample and Sampling Procedures}

Varkevisser (2003) explains sampling as the process of selecting a number of study units from a defined population. There were 53 pre-schools in Universal Basic Education in the Obio-Akpor Local Government Area. Using the Krejcie and Morgan (1970) table for determining sample size, a sample of 45 pre-schools out of the 53 pre-schools in Universal Basic Education in the Obio-Akpor Local Government Area were selected for the study. There were 45 teachers in the nursery two (2) classes and 45 head teachers in the 45 selected preschools in Universal Basic Education in the Obio-Akpor Local Government Area. In all, 90 respondents (45 nursery two teachers and 45 head teachers) constituted the sample size for the study.

The simple random sampling (lottery method) was used to select the 45 out of 53 pre-schools in the Obio-Akpor Local Government Area. Similarly, both the nursery two teachers and head teachers in the 45 pre-schools were selected for the study using the simple random sampling procedure (simple random sampling) because, the researcher gave equal chance to each of the respondents of being selected due to the fact that, they can equally provide the necessary information needed for the study with regards to the teacher resources available to facilitate inclusive education in pre-schools.

\section{RESULTS}

The following presents the results and discussions of data collected to answer the four research questions formulated to guide the study. It comprised data from the questionnaire.

\subsubsection{Research Question 1: What are the views of teachers regarding teacher resources for inclusion in pre-schools?}

This research question intended to find out the views of teachers regarding teacher resources available for pre-school inclusion. Table 1 provides the responses gathered from the questionnaires from the teachers.

Table 1: Views of Teachers on teacher resources for inclusion $(n=45)$

\begin{tabular}{|l|c|c|}
\hline \multicolumn{1}{|c|}{ Statements } & M & SD \\
\hline $\begin{array}{l}\text { I am adequately prepared to handle the disabilities of } \\
\text { children. }\end{array}$ & 1.04 & .81 \\
\hline $\begin{array}{l}\text { I think that teachers must have concise rules for inclusive } \\
\text { classrooms and ensure that students know and } \\
\text { understand the rules that are set. }\end{array}$ & 2.78 & .83 \\
\hline $\begin{array}{l}\text { I am well trained to assist learners with varying degrees } \\
\text { of learning difficulties to improve in their academic } \\
\text { performance. }\end{array}$ & 3.21 & .66 \\
\hline $\begin{array}{l}\text { I am able to adapt the curriculum materials to address the } \\
\text { needs of pupils with disabilities. }\end{array}$ & 1.36 & .75 \\
\hline $\begin{array}{l}\text { I am competent in selecting learning experiences that } \\
\text { meet the needs of all learners in inclusive classrooms. }\end{array}$ & 3.38 & .51 \\
\hline $\begin{array}{l}\text { I am able to help learners without disabilities develop } \\
\text { positive attitudes towards their peers with disabilities. }\end{array}$ & 3.31 & .65 \\
\hline $\begin{array}{l}\text { I am able to guide and assist parents of disabled children } \\
\text { with knowledge and skills concerning how to assist their } \\
\text { wards with various needs at home. }\end{array}$ & 3.20 & .68 \\
\hline
\end{tabular}

Source: Field Data, 2019

Scale: $\quad 1=$ Disagree, $2=$ Uncertain, $3=$ Agree

Mean of means $=2.61$ Mean of standard deviation $=0.70$
Generally, a careful look at Table 1 shows that the teachers at the Obio-Akpor Local Government Area agreed to the majority of the statements posed to them to find out their views on $\mathrm{r}$. In line with this, a mean of means of 2.61 and a mean of standard deviation of 0.70 were achieved for the items. The following instances from the individual items attest to that fact:

From Table 1, a mean of 1.04 and 0.81 standard deviation was attained meaning that majority of the respondents disagreed that, they are adequately prepared to handle the behavioural disorders of children. This finding is in agreement with Avramidis and Norwich (2002) who indicated that, although most teachers have positive attitudes toward inclusion, teachers did not feel prepared for teaching learners with exceptional needs, especially in the case of children with severe learning difficulties and behavioural/emotional disorders. In line with the statement; "I think that teachers must have concise rules for inclusive classrooms and ensure that learners know and understand the rules that are set", a mean of 2.78 and a standard deviation of .83 were attained for the statement. Therefore, the majority of the teachers agreed to the statement. Similarly, the majority of the teachers agreed that they are well trained to assist learners with varying degrees of learning difficulties to improve in their academic performance. With this, a mean of 3.21 and a standard deviation of .66 were achieved for the item. In line with this finding, Booth (1996) explained that, inclusion is also seen as a process of addressing and responding to the diversity of needs of all learners through increasing participation in learning, cultures and communities, and reducing exclusion within and from education as explained in. It involves changes and modifications in content, approaches, structures and strategies, with a common vision which covers all children of the appropriate age range and a conviction that it is the responsibility of the regular system to educate all children. However, the majority of the teachers indicated that they were unable to adapt the curriculum materials to address the needs of pupils with and without disabilities. Here, a mean of 1.36 and a standard deviation of .75 were attained for the statement. General education teachers will be faced with the challenges of adapting materials and equipment to meet the needs of the children match the structure of the academic subject and objectives of the lesson to be taught (Obi, 2013).

As to whether teachers were competent in selecting learning experiences that meet the needs of all learners in inclusive classrooms, the majority of the teachers agreed to the statement. With this, a mean of 3.38 was attained as well as a standard deviation of .51. Also, the majority of the teachers agreed that they are able to help learners without disabilities develop positive attitudes towards their peers with disabilities. Here, a mean of 3.31 and a standard deviation of .65 were achieved for the statement. This view is in agreement with Dyson (1999), who on the discourse of politics in inclusion is concerned with the extent to which a particular school system realized and protects the rights of its students and monitors power distribution accordingly. This discourse is concerned 
with the eradication of injustices in schools. If one takes a look at Dyson's explanation of the political paradigm of inclusion, one can understand why some definitions of inclusive education focus on equity and social justice in education. One of such examples is found in Engelbrecht (1979) and Adelowo, (2006) who see inclusive education as a proposed strategy for achieving a democratic society. Again, a mean of 3.20 and a standard deviation of .68 were attained which indicate that, the respondents agreed that they were able to guide and assist parents of disabled children with knowledge and skills concerning how to assist their wards with various needs at home. Thus the majority of the teachers agreed to the statement.

From the foregoing, it can be concluded that, the majority of the teachers shared positive views on the support services available. With this, the teachers agreed that: there was the need to have concise rules for inclusive classrooms; they should be well trained to assist learners with varying degrees of learning difficulties to improve on their academic performance; they were competent in selecting learning experiences that meet the needs of all learners in inclusive classrooms; they were able to help learners without disabilities develop positive attitudes towards their peers with disabilities; and were able to guide parents of disabled children with knowledge and skills concerning how to assist their wards with various needs at home. However, the teachers indicated that they were not adequately prepared to handle the disabilities of children; and were unable to adapt the curriculum materials to address the needs of pupils with and without disabilities.

\subsubsection{Research Question 2: What teacher resources are available to facilitate inclusion?}

This section reports the responses from both teachers and headteachers to the question, "What teacher resources are available to facilitate inclusion?" Table 2 illustrates the views of the teachers and headteachers concerning the teacher resources available to facilitate inclusion.

Table 2: Teacher Resources Available to Facilitate Inclusion $(n=45)$

\begin{tabular}{|c|c|c|c|}
\hline Statement & $\begin{array}{c}\text { Disagree } \\
\text { N (\%) }\end{array}$ & $\begin{array}{c}\text { Uncertain } \\
\text { N (\%) }\end{array}$ & $\begin{array}{c}\text { Agree } \\
\text { N (\%) }\end{array}$ \\
\hline $\begin{array}{c}\text { Tape recorders are available in my } \\
\text { school. }\end{array}$ & $36(80.0)$ & $1(2.2)$ & $8(17.8)$ \\
\hline $\begin{array}{c}\text { There are varieties of real materials in } \\
\text { my school for teaching pupils in my } \\
\text { school. }\end{array}$ & $3(6.7)$ & $6(13.3)$ & $36(80.0)$ \\
\hline $\begin{array}{c}\text { Hearing aid and optical devices such } \\
\text { as magnifiers, telescope and lenses } \\
\text { are available for use by pupils with } \\
\text { auditory and visual impairments. }\end{array}$ & $37(82.2)$ & $4(8.9)$ & $4(8.9)$ \\
\hline $\begin{array}{c}\text { A resource teacher is attached to my } \\
\text { school to help pupils with disabilities } \\
\text { to cope. }\end{array}$ & $20(44.5)$ & $15(33.3)$ & $10(22.2)$ \\
\hline $\begin{array}{c}\text { Guidance and counseling services are } \\
\text { rendered to pupils including pupils } \\
\text { with disabilities in my school. }\end{array}$ & $24(53.3)$ & $12(26.7)$ & $9(20.0)$ \\
\hline
\end{tabular}

www.rsisinternational.org

\begin{tabular}{|c|c|c|c|}
\hline $\begin{array}{c}\text { Indirect services such as supporting } \\
\text { the class teacher to plan lessons, } \\
\text { select the right materials for pupils } \\
\text { with disabilities are available and } \\
\text { practiced in my school. }\end{array}$ & $29(64.4)$ & $8(17.8)$ & $8(17.8)$ \\
\hline
\end{tabular}

Source: Field Data, 2019

From Table 2, it is obvious that most of the teachers disagreed to most of the statements posed to them concerning the availability of material resources to facilitate inclusion. Individual items are relented in the discussion below.

In relation to the statement, "Tape recorders are available", the majority of the teachers disagreed to the statement. With this, 36 respondents representing $80.0 \%$ disagreed, 1 respondent representing $2.2 \%$ was uncertain, and 8 respondents $17.8 \%$ agreed. Also, 36 respondents representing $80.0 \%$ disagreed, 6 respondents representing $13.3 \%$ were uncertain, and 3 respondents representing $6.7 \%$ agreed that, there are varieties of real materials for teaching pupils in their school. Thus the majority of the teachers disagreed to the statement. Instructional materials are essential for effective teaching and learning. This is because in a mainstreamed setting, instructional materials are used by the teacher to facilitate learning for the individual child (Obi, 2013). But this becomes a problem in most schools due to inadequate funds to procure them. The Ministry of Education and Ghana Education Service must see it that the capitation grants and other logistics reach schools on time for teachers to procure the needed materials for teaching. Deku and Vanderpuye (2008) were of the view that the choice of instructional materials greatly influences any educational programme. They continued that materials available influence content, quality, and general efficiency of the instructional programme, teachers and schools must be provided with relevant materials to the needs of students including pupils with low vision.

Similarly, the majority of the teachers disagreed that hearing aid and optical devices such as magnifiers, telescope and lenses were available for use by pupils with auditory and visual impairments. Here, 37 respondents representing $82.2 \%$ disagreed, 4 respondents representing $8.9 \%$ were uncertain, and 4 respondents representing $8.9 \%$ agreed to the statement. Also, teachers disagreed to the statement; "A resource teacher is attached to my school to help pupils with disabilities to cope". With this item, 20 respondents representing $44.5 \%$ disagreed, 15 respondents representing $33.3 \%$ were uncertain, and 10 respondents representing $22.2 \%$ agreed to the statement. Similarly, teachers disagreed to the statement: "Guidance and counseling services are rendered to pupils including pupils with disabilities in my school". This is because, 24 respondents representing $53.3 \%$ disagreed, 12 respondents representing $26.7 \%$ were uncertain, and 9 respondents representing $20.0 \%$ agreed to the statement. In line with the statement; "Indirect services such as supporting the class teacher to plan lessons, select the right materials for pupils with disabilities are available and practiced in my school", 29 teachers representing 64.4\% disagreed, 8 teachers representing $17.8 \%$ were uncertain, and 8 teachers 
representing $17.8 \%$ agreed to the statement. Therefore, the majority of the teachers disagreed to the statement.

From the foregoing, it can be concluded that, a lot of the material resources to facilitate inclusion were not available. This is because, the teachers indicated that; tape recorders; hearing aid and optical devices such as magnifiers, telescope and lenses were not available. Also, the schools did not have a resource teacher to support teachers manage children with disabilities; guidance and counseling services were not rendered for pupils with and without disabilities; and indirect services such as supporting the class teacher plan lessons, select the right materials for pupils with disabilities were not available for the teachers in the schools. Again, varieties of real materials for teaching pupils with special needs were not available.

\subsubsection{Summary of Main Findings}

The study examined the teacher resources available for the inclusion of children with disabilities in pre-schools within Obio-Akpor in Nigeria. Specifically, the study sought to assess the views of teachers regarding the teacher resources available, and, the teacher resources available to facilitate inclusive education. The research design adopted for this study was the descriptive survey research design. The simple random sampling technique was employed to select 90 respondents (45 nursery two teachers and 45 head teachers) for the study. Two sets of questionnaires (for the teachers and headteachers) was adopted for the study. The data that was gathered for the study was analyzed using the descriptive statistics such as frequencies, percentages, means and standard deviations.

\subsubsection{Key Findings}

The following were the main findings of the study:

1. It was realized that, the majority of the teachers shared positive views on the support services available. However, the teachers indicated that they were not adequately prepared to handle the disabilities of children; and were unable to adapt the curriculum materials to address the needs of pupils with and without disabilities.

2. Also, it was realized that, a lot of the teacher resources to support teachers in inclusive education were not available. With this, both the teachers and headteachers indicated that; tape recorders; hearing aid and optical devices such as magnifiers, telescope and lenses were not available. Also, the schools did not have a resource teacher to support teachers to manage children with disabilities; and guidance and counseling services were not rendered for pupils with and without disabilities.

\section{CONCLUSIONS}

On the basis of the findings, it can be concluded that, the majority of the teachers shared positive views on the support services available. However, the fact that teachers indicated that they were not adequately prepared to handle the disabilities of children; and were unable to adapt the curriculum materials to address the needs of pupils with and without disabilities presupposes that, the teachers did not have adequate knowledge and preparation on inclusive education.

Also, it can be concluded that, a lot of teacher resources to support inclusive education were not available. With this, both teachers and headteachers indicated that; tape recorders; hearing aid and optical devices such as magnifiers, telescope and lenses were not available. Also, the schools did not have a resource teacher to support teachers manage children with disabilities; and guidance and counseling services were not rendered for pupils with and without disabilities. This presupposes that, lack of adequate teacher resources to enhance effective delivery of inclusive education could be a contributory factor affecting teachers in their delivery of inclusive education to students.

\section{RECOMMENDATIONS}

Based on the observations and findings from this research study, the following recommendations are made:

1. Experts in special education are encouraged to visit schools especially where more cases of disabilities are profound to educate teachers and parents on disability issues. These experts should organize inservice training for teachers and also prepare teachers on how to handle the behavioural disorders of children with and without exceptional needs/disabilities; as well as how to adapt the curriculum materials to address the needs of pupils with and without disabilities.

2. Teaching aids should be made available by the Federal Ministry of Education and other stakeholders to teach the curriculum to meet the needs of all the category of children in the classrooms. Headteachers should make guidance and counseling services available to learners. Also, materials needed for effective alternative assessment in inclusive education should be provided by stakeholders like "Friends of the Disabled" and "Curriculum and Research Development Division" in collaboration with the Federal Ministry of Education.

3. Again, the Federal Ministry of Education should make funds available for the support of inclusive education. The Federal Ministry of Education must see it that the capitation grants and other logistics reach schools on time for teachers to procure the needed materials for teaching.

\section{REFERENCES}

[1] Adelowo, T.O. (2006). Education and human development of the special needs child: A global view. In T.C. Obani (Ed). Teaching pupils with special educational needs in the regular UBE classroom. Ibadan-Nigeria: Book-Builders. 1-36.

[2] Ainscow, M. (1997). Developing inclusive education system: what are the levels for change? Journal for Educational change 6, 109124. 
[3] Amedahe, F. K. (2002). Fundamentals of educational research methods. Cape Coast: UCC.

[4] Amedahe, F. K., \& Gyimah, E.A. (2005). Introduction to educational research. Cape Coast: Centre for Continuing Education.

[5] Anaby D., Law M., Coster, W., Bedell, G., Khetani, M., \& Teplicky, R. (2014). The mediating role of the environment in explaining participation of children and youth with and without disabilities across home, school, and community. Washington, DC: Gallaudet University Press.

[6] Avramidis, H. L., \& Norwich, J. F. (2002). A validation study of the performance indicators and learner outcomes of Kentucky's alternate assessment for students with significant disabilities. The Journal of the Association for Persons with Severe Handicaps, 24, 100-110.

[7] Bernheimer, L. P., Gallimore, R., \& Weisner, T. S. (1990). Ecocultural theory as a context for the individual family service plan. Journal of Early Intervention, 14(3), 219-233.

[8] Bhandarkar, P. C. \& Wilkinson, TS. (2010). Methodology and Techniques of Social Research. Mumbai: Himalaya.

[9] Booth, T. (1996). Index for inclusion: Developing learning and participation in schools. Bristol: Centre for studies on Inclusive Education.

[10] Deku, P., \& Vanderpuye, I. (2008). Assessing instructional strategies: A case study of selected regular schools in Ghana. Implication for Inclusive education. African Journal of Special Educational Needs, 5(4), 67-78.

[11] Deng, H. (2010). Emerging patterns and trends in utilizing electronic resources in a higher education environment: an empirical analysis. New library world, $\quad$ 111(3-4), 87-103.

[12] Dyson, A. (1999), Special needs in the twenty first century: where have we been and where we're going (The Ron Guilford lecture). British Journal of Special Education of Special education, 28 (1), 24-49.

[13] Eleweke C. J. (2016). Nigeria's national policy on special education: A critical appraisal.

http://www.firsteternal.com/africanadeleweke_001.html (Retrieved: 11/05/2016)

[14] Enabling Education Network (EENET) (2004). Preparing new teachers for inclusive schools and classrooms. http://www3.interscience.wiley.com. (Retrieved: 02/04/2018)

[15] Engelbrecht, P. (1997). A theoretical framework for inclusive education. In P. Engelbrecht, L. Green, S. Naicker \& L. Engelbrecht (Eds) Inclusive education in action in South Africa. Pretoria: Van Schaik. 3-12.

[16] Fraenkel, J. R., \& Wallen, N.E. (2003). How to design and evaluate research in education ( $4^{\text {th }}$ ed.). New Jersey: The McGraw-Hill Companies, Inc.

[17] Gardner, M., \& Kelly, U. A. (2008). Introduction: Narrating transformative learning in education. In M. Gardner \& U. A. Kelly
(Ed.), Narrating transformative learning in education (pp. 105201). New York: Macmillan.

[18] Garuba, A. (2003). Inclusive education in the 21st century: Challenges and opportunities for Nigeria. Asia Pac. Disab. Rehab. J., 2003; 14(2):191-200.

[19] Hayford, S. K. (2007). Continuous assessment and lower attaining pupils in primaryand junior secondary schools in Ghana. $\mathrm{PhD}$ Thesis: University of Birmingham. http://etheses.bham.ac.uk/128/1/Hayford08PhD.pdf. （Retrieved: 12/09/2019)

[20] Hsu, C. \& Sandford, B. (2010). Instrumentation. In Neil J. Salkind $(E d$.$) , encyclopedia of research design. Thousand Oaks, CA: Sage$ Publications.

[21] Krejcie, R.V., \& Morgan, D.W. (1970). Determining sample size for research Activities. Educational \& Psychological Measurement, 30, 607-610.

[22] Kwabia, K. (2006). Theory in social research: The link between literature and observation. Accra: Woeli Publishing Services.

[23] Lidsay, G. (2003), Educational psychology and the effectiveness of inclusive education/mainstreaming. British journal of Educational psychology. 50 (4) 482-502.

[24] Moore, C., \& Gilbreath, D. (1998). Educating students with disabilities in general. Retrieved from $\mathrm{mrsh} /$ files/Rapport.SEH_.pdf.

[25] Nguyet, D. T., \& Ha, L. T. (2010). How to guide series: Preparing teachers for inclusive education. CRS Vietnam: Catholic Relief Services.

[26] Obi, F. (2013). An effective parenting of children with special needs. A guidebook for parents, special educators, counselors and related professional. Ibadon: Hope Publications.

[27] Obiakor, F. E., \& Offor, M. T. (2012). Special education contexts, problems, and prospects in Nigeria. In: Winzer MA, Mazurek K. editors. International practices in special education: Debates and challenges. Washington, DC: Gallaudet University Press.

[28] Osuala, E. C. (2005). Introduction to research methodology. Onitsha: African First Publishers.

[29] Shuttleworth, M. (2008). Descriptive research design. http://www.experimentresources.com/descriptive-researchdesign.html (Retrieved: 10/10/2020)

[30] Sweetland, J. (2008). Making dissatisfaction divine: An inspired approach to whole school reform. International Journal of Whole Schooling, 4(1), 1-9.

[31] UNESCO (2009). Reaching the marginalized: How to approach inclusive education. UNESCO International Conference, Düsseldorf, Germany, 10-11 September 2009.

[32] Varkevisser, C. (2003). Research methodology. ( $3^{\text {rd }}$ ed.). London: Oxford University Press. 